\title{
STRUCTURE, COMPOSITION AND DIVERSITY OF FOREST ALONG THE ALTITUDINAL GRADIENT IN THE HIMALAYAS, NEPAL
}

\author{
PANDEY, K. P. ${ }^{1}-$ ADHIKARI, Y. P. ${ }^{* 2}-$ WEBER, ${ }^{1}{ }^{1}$ \\ ${ }^{1}$ Institute of Silviculture \\ Department of Ecology and Ecosystem Management \\ TUM School of Life Sciences Weihenstephan \\ Technische Universität München \\ Hans-Carl-von-Carlowitz-Platz 2, D- 85354 Freising, Germany \\ ${ }^{2}$ Geobotany, Department of Ecology and Ecosystem Management \\ TUM School of Life Sciences Weihenstephan \\ Technische Universität München \\ Hans-Carl-von-Carlowitz-Platz 2, D- 85354 Freising, Germany \\ (phone: +49-8161-71-5855; fax: +49-8161-71-4738) \\ *Corresponding author \\ e-mail: adhikari@wzw.tum.de \\ (Received $10^{\text {th }}$ Aug 2015; accepted $29^{\text {th }}$ Jan 2016)
}

\begin{abstract}
The aim of this study was to assess the structure (stem density, height, and basal area), composition and diversity in relatively undisturbed forests along an altitudinal gradient from $2000 \mathrm{~m}$ asl to $3900 \mathrm{~m}$ asl of Langtang National Park in Central Himalaya. The forest stands along the altitudinal gradient were studied on 20 sampling plots of two sub zones of the Temperate and Subalpine zone. Tsuga dumosa was the ecologically most important species in the Upper and the Lower Subalpine zone with high important value index (IVI = 124.31). Quercus semecarpifolia and Lithocarpus elegans were the ecologically most important species in the Upper and the Lower Temperate zone with IVI of 66.64 and 46.39 respectively. Similarly, indicator species' analysis was performed to know the preferences of tree species within the vegetation zones. Rhododendron campanulatum is highly significant $(p<0.001)$ and Tsuga dumosa significant $(0.05<p<0.01)$ in the Upper Subalpine zone, whereas Rhododendron anthopogon prefers the Lower Subalpine zone with significant value $(0.01<p<0.001)$. Only the Quercus semecarpifolia prefers the Upper Temperate zone. There was no specific trend in the structure along the altitudinal gradient. The Shannon diversity index ranged from 1.10 to 2.34 with the highest value in the Lower Temperate zone. Both Simpson index (0.89) and Evenness (0.86) were high in the Lower Temperate zone. From this study it is concluded that the contribution of forest composition in terms of species richness and Shannon diversity is significant in Lower Temperate zone. The Upper Subalpine zone has less diversity and may also be less endangered by human impact but may profit from climate change in the future.
\end{abstract}

Key words: vegetation zone, density, basal area, diversity, altitudinal gradient, Nepal

Nomenclature of tree species WCSP (2015).

\section{Introduction}

The integrated knowledge of the structure, composition and diversity of plant species is the basis for sustainable management strategies in different forest ecosystems (Gutierrez and Huth, 2012). Forest ecosystems (structure, composition and diversity of the species) play also an important role in the global carbon budget as they sequester carbon dioxide from the atmosphere and act as huge C-pools (Canadell et al., 2007; Denman et al., 2007). Forest stands, forest structure and diversity are also important for 
canopy community (Adhikari et al., 2012a; Adhikari et al., 2015). Covering about one third of the earth's land surface, forest ecosystems are a major component in the proposed strategies for the mitigation of atmospheric $\mathrm{CO}_{2}$ emissions (Richards and Stokes, 2004; Neilson et al., 2006). In this context non-managed forests are of specific interest as they include high carbon stocks. Consequently, Weber (2001) highlighted the need for the protection of natural forests as carbon reservoirs. However, so far the characteristics of forest ecosystems of the world's protected area network remains poorly studied (Campbell et al., 2008). In this study we present data of protected forests along an altitudinal gradient in the Langtang National Park, Nepal.

In Nepal approximately $29 \%$ of the total land is covered by forest (DFRS, 1999) consisting of 35 forest types (Stainton, 1972) along the elevational gradient from $60 \mathrm{~m}$ asl to tree line at around $4000 \mathrm{~m}$ asl. Protected areas constitute about $20 \%$ of Nepal's total land area (Bhuju et al., 2007) and represent 47 types of vegetation (Shrestha, 2001). Mountain ranges have a special status due to its characteristic to increase geodiversity and harbour at least a third of terrestrial plant species diversity (Barthlott et al. 1996). Researchers around the world for centuries have extensively studied mountains as steep ecological gradients and hotspots of biodiversity (Körner, 2007). Alexander von Humboldt was the first to describe the latitudinal gradient of vegetation and the corresponding altitudinal gradient of vegetation that led to basic understanding of species composition and diversity along an altitudinal gradient (Fischer, 2011).

Altitudinal zonation of vegetation is one of the most striking gradational patterns of vegetation (Oshawa, 1977, and 1984) and much information is accumulated on its local patterns. Theoretically, the division of vegetation zones should be based on the climax vegetation which refers to the forest structure. Research to describe the vertical and horizontal distribution of the vegetation of the Himalayas is still ongoing considering the spatial differences in forest canopy (Adhikari and Fischer, 2011; Adhikari et al., 2016) and diversity of the plant species between particular sections of this mountain range (Polunin and Stainton, 2000). Several scientists have studied the altitudinal climax vegetation zonation on the slopes of Himalaya (e.g., Schweinfurt, 1957; Stainton, 1972; Dobremez, 1976). The basic pattern of vegetation distribution along altitudinal gradients is controlled by solar radiation, temperature and humidity. However, these factors can vary on small scales due to varying environmental factors like aspect, slope, altitude (here we focused on) and exposure. The altitudinal distribution and the main tree species composition of the forest communities in Nepalese Himalayas show an extreme complexity attributed to bioclimatic diversity.

Protected areas have been implemented to maintain natural forest structures and biodiversity by restricting direct anthropogenic impacts. Consequently, knowledge on the structure and composition of the protected forests along the high altitude can be important as a reference in the context of the initiatives to reduce emissions from deforestation and forest degradation (REDD) (UNFCCC, 2007). It also provides input to the development of strategies for the selection of taxa in reforestation, particularly for the conservation of canopy community, especially flora (Adhikari et al., 2012a; b; Adhikari et al., 2015). However, to assess the role of existing protected areas and forest stands in REDD, a comprehensive assessment of their potential elements is needed (Scharlemann et al., 2010).

In this study, we generate knowledge on the structure, composition and diversity of the forest in the Langtang National Park (hereafter LNP) in central Himalayas. The study is based on a thorough floristic tree inventory of four sub vegetation zones of two 
zones. The research aims to answer the question of whether elevation gradient affects composition, structure and diversity of tree species along altitudinal gradient by (i) comparing composition and structure of stands in different zones and (ii) comparing diversity patterns of forest stands along altitudinal gradient.

\section{Materials and Methods}

\section{Study area}

The study was conducted in the Langtang National Park, Rasuwa district, Nepal. Field work was carried out from December 2013 to February 2014. The National Park $\left(28^{\circ} 10^{\prime} 26^{\prime}\right.$ ' N $\left.85^{\circ} 33^{\prime} 11^{\prime \prime}, \mathrm{E}\right)$ extends from $32 \mathrm{~km}$ north of Kathmandu to the NepalChina (Tibet) border in the Central Himalayan region of Nepal (Fig. 1). We selected the National Park as our study area, because i) it has a clear altitudinal gradient, ii) it is a relatively less disturbed area, and iii) it has typical forest structure which we couldn't find outside the National Park.

It is the second largest national park established in 1976 to preserve this unique ecosystem of significant value to the world's biodiversity. The study area has cool temperate monsoon climate with annual precipitation of $2078 \mathrm{~mm}$ (total). The annual mean temperature at $2000 \mathrm{~m}$ asl is $15.3^{\circ} \mathrm{C}$, and there is a $6{ }^{\circ} \mathrm{C}$ drop in temperature for every $1000 \mathrm{~m}$ rise in altitude (Government of Nepal, Meteorological Service Office).

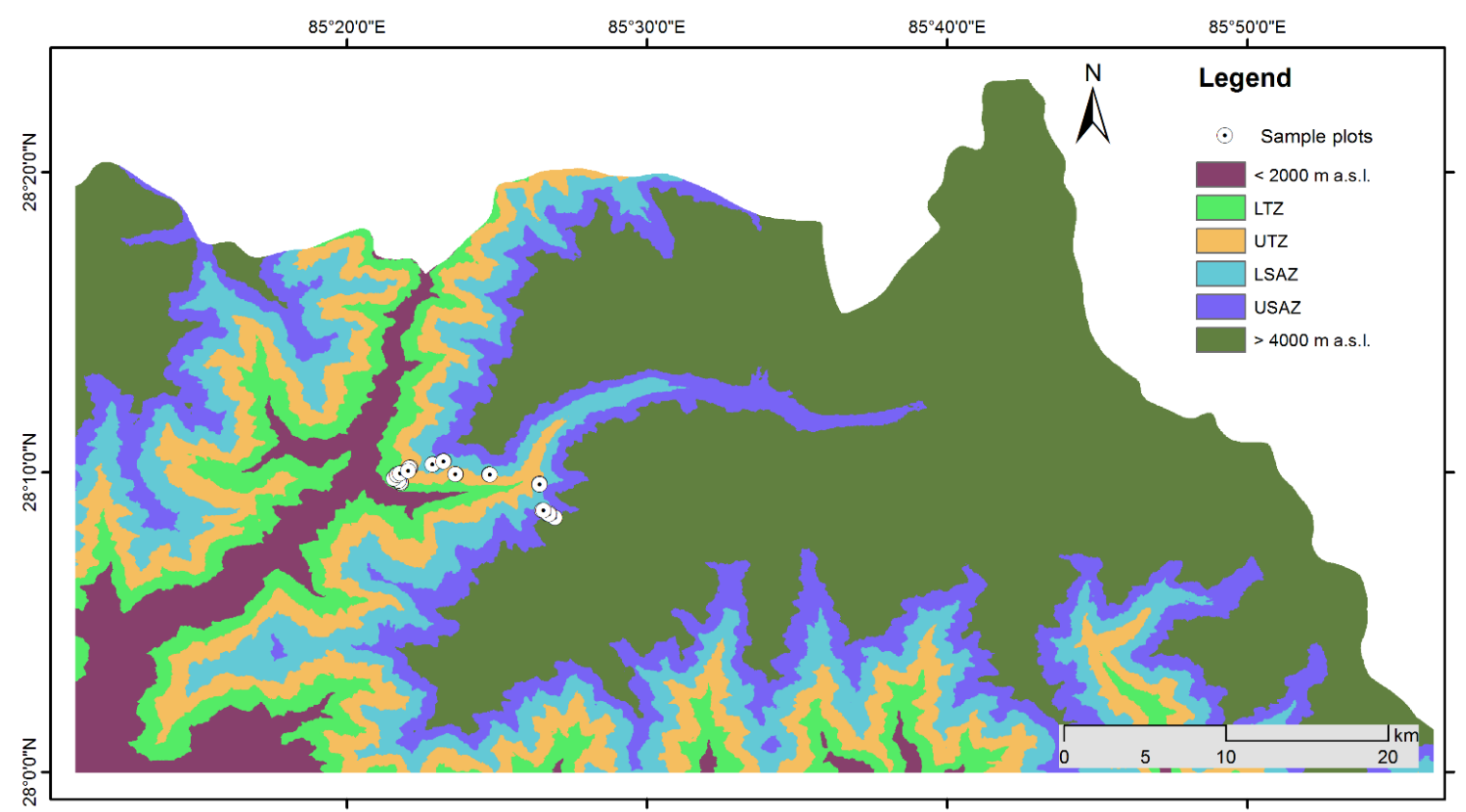

Figure 1. The study area: Dots in the map represent the sample plots. Abbreviation in legend are $(L T Z=L o w e r$ Temperate zone; UTZ= Upper Temperate zone; $L S A Z=$ Lower Subalpine zone; USAZ=Upper Subalpine zone).

\section{Forest vegetation of study area}

The diverse topography, geology, and climatic patterns have resulted in a great variety of vegetation types. LNP comprises 18 forest types from Subtropical (1000- 
$2000 \mathrm{~m}$ asl) to Nival (above $5000 \mathrm{~m}$ asl) vegetation zones found in Nepal (Shrestha, 2001). The total forest area of LNP is about $25 \%$ of the total area. The composition of all vegetation zones has been already mentioned in the Langtang National Park management plan (1977) and Dobremez et al. (1976), however, we have described here structure, IVI and diversity of the species in Upper and Lower Subalpine zone, and Upper and Lower Temperate zone respectively. For this study, we categorized vegetation zones within $2000 \mathrm{~m}$ to $3900 \mathrm{~m}$ asl equally in four zones. The first zone is Upper Subalpine zone (3500-4000 m asl), the second zone is Lower Subalpine zone (3000-3500 $\mathrm{m}$ asl). Similarly, the third and fourth zones are the Upper Temperate (2500-3000 $\mathrm{m}$ asl) and Lower Temperate zone (2000-2500 $\mathrm{m}$ asl) respectively.

\section{Field sampling}

A systematic sampling design for the selection of sampling plots along the elevation gradient was used. The sampling plots were surveyed with a square shaped at each interval of $100 \mathrm{~m}$ altitude above $2000 \mathrm{~m}$ up to the tree line around $3900 \mathrm{~m}$ (Fig. 1). The sampling plots size $(20 \times 20 \mathrm{~m})$ were identified using Geographic Positioning System (elevation, latitude, and longitude) as suggested by Mueller-Dombois and Ellenberg, 1974; Chytry et al., 2003. Altogether 20 sampling plots for trees $(\geq 5 \mathrm{~cm}$ diameter at breast height i.e. dbh) were laid down. Because there were only very few possibilities to enter the area (very steep slopes, rugged terrain), the trekking trail from Ghatte river to Lauribinayak section was used as the basis for the elevation gradient. In order to eliminate anthropogenic influences on the forest, all plots were laid at least $100 \mathrm{~m}$ away from trekking trails. In each sampling plot, we recorded name of tree species, height and dbh. Height was measured with the Sunnto Clinometer as described by Pretzsch (2009).

\section{Data analysis}

\section{Composition of tree species}

For each species, values of frequency, density and dominance were calculated following the methods of Curtis and McIntosh (1951). A species IVI is a summation of three values: (1) the species' relative dominance or percent basal area coverage relative to other species in the stand; (2) relative density or percent occurrence per unit area relative to other species; and (3) relative frequency or percent probability of occurrence in a sample plot relative to other community species.

\section{Density, frequency, and dominance}

Density, frequency, and dominance and their relative values were calculated by using following formulae:

$$
\text { Density (per hectar) }=(D)=\frac{\text { Total no.of individuals of a species found }}{\text { Total area examined }} \times 10,000 \quad \text { (Eq. 1) }
$$

Relative Density of species $A=(R D)=\frac{\text { No.of individulas of species } A}{\text { Total no. of individuals of all species }} \times 100 \quad$ (Eq. 2) 


$$
\begin{gathered}
\text { Frequency }(\% \text { of plot })=(\mathrm{F})=\frac{\text { No.of quadrats in which species occurs }}{\text { Total no.of quadrats examined }} \times 100 \\
\text { Relative Frequency of species } \mathrm{A}=(\mathrm{RF})=\frac{\text { Frequency of species } \mathrm{A}}{\text { Sum of frequencyvalues of all species }} \times 100 \text { (Eq. 4) } \\
\text { Dominance }=(\mathrm{Do})=\frac{\frac{\pi(\mathrm{dbh}) 2}{4}}{\text { Relative dominance }=}=\frac{\text { total basal area of all species }}{4} \times 100
\end{gathered}
$$

Indicator values were calculated according to Dufrêne and Legendre (1997) with PCord version 6 (McCune and Mefford, 2011).

\section{Structure of forest stands}

The structure of the forests along the altitudinal gradient was described based on three structural features: diameter size class distribution, basal area and height. Trees in each sampling plot were categorized in three diameter classes $(<10,10-29.5$ and $\geq 30$ $\mathrm{cm} \mathrm{dbh)}$ and the percentage of trees in each diameter class was analyzed for each vegetation zone. The total basal area of each tree species inside each plot was calculated and then average basal area for each vegetation zone was obtained. Similarly, the height of each species inside the sampling plots was measured and then average between the plots was taken to obtain an average height for vegetation zones.

\section{Diversity of tree species}

Simpson's diversity index (Equation 7) is one of the most meaningful and robust diversity measures available. The index is calculated as proportion of species $i$ relative to the total number of species (pi) (Simpson, 1949).

$$
\mathrm{D}=1-\frac{\sum_{i=1}^{S} n_{i} \cdot\left(n_{i}-1\right)}{N \cdot(N-1)}
$$

Where $n_{i}$ is the number of individuals in the species $i$

$s$ is the number of species

$\mathrm{N}$ total individuals (species).

Shannon's index is calculated from the equation:

$$
H^{\prime}=-\sum_{i}^{s} p_{i} \cdot \log p_{i} \text { Where } p_{i}=\frac{n_{i}}{N}
$$

Where $p_{i}$ proportional abundance of species $i$ 
$s$ is the number of species

As a heterogeneity measure, the Shannon index takes the degree of evenness in species and abundance into account. Evenness $\mathrm{E}$ is calculated as proportion of observed and maximal diversity (Pielou, 1969):

$$
\mathrm{E}=\frac{H^{v}}{H_{\max }}
$$

Where $\mathrm{E}=$ evenness (range $0-1)$

$H^{\prime}$ is Shannon index

$H_{\text {max }}=(\ln \mathrm{s})=$ maximum possible diversity

$s$ is the number of species.

\section{Results}

\section{Forest composition}

Altogether 25 species belonging to 16 families were recorded. The identified species represent the flora of the majority of patches forming the forest along an altitudinal gradient from 2000 to $3900 \mathrm{~m}$ asl. On the basis of relative density, relative basal area and relative frequency, the four vegetation zones differed in the most important species. All field inventory sheet, recorded tree species, their average height and dbh in each vegetation zone is synthesized in (Appendix Table Al).

In the Upper Subalpine zone (3500-3900 m asl), only four species were recorded (Table 1). Among them Tsuga dumosa was the ecologically most important species for this zone with an IVI value 124.31. The second important tree species was Juniperus recurva with an IVI value 99.10. The other associated tree species Rhododendron campanulatum and Betula utilis had IVI values of 67.94 and 8.65 respectively. In the Lower Subalpine zone (3000-3500 m asl), eight species were recorded (Table 1). As in the upper zone Tsuga dumosa was the ecologically most important species with an IVI value of 97.25. The second important tree species was Rhododendron anthopogon with an IVI value of 86.45. Among the other six associated tree species, Viburnum spp. was the least important species.

Table 1. Recorded tree species and their composition in four altitudinal zones of the study area, ranked by importance value index (IVI)

\begin{tabular}{|c|c|c|c|c|c|c|c|c|}
\hline \multirow[t]{2}{*}{ Rank } & \multirow[t]{2}{*}{ Species } & \multicolumn{2}{|c|}{ Stem density } & \multicolumn{2}{|c|}{$\begin{array}{l}\text { Basal area } \\
\left(\mathbf{m}^{2} / \mathbf{h a}\right)\end{array}$} & \multicolumn{2}{|c|}{ Frequency } & \multirow[t]{2}{*}{ IVI } \\
\hline & & $\begin{array}{l}\text { no/ } \\
\text { ha }\end{array}$ & $\begin{array}{l}\text { RD } \\
(\%)\end{array}$ & $\mathbf{B A}$ & $\begin{array}{l}\text { RBA } \\
(\%)\end{array}$ & $\mathbf{F}$ & $\begin{array}{l}\text { RF } \\
(\%)\end{array}$ & \\
\hline \multicolumn{9}{|c|}{ Upper Subalpine zone } \\
\hline 1 & Tsuga dumosa & 305 & 36.31 & 36.65 & 49.54 & 1 & 38.46 & $\begin{array}{r}124.3 \\
1\end{array}$ \\
\hline 2 & Juniperus recurva & 335 & 39.88 & 32.43 & 43.83 & 0.4 & 15.38 & 99.10 \\
\hline 3 & $\begin{array}{l}\text { Rhododendron } \\
\text { campanulatum }\end{array}$ & 195 & 23.21 & 4.64 & 6.27 & 1 & 38.46 & 67.94 \\
\hline 4 & Betula utilis & 5 & 0.60 & 0.27 & 0.36 & 0.2 & 7.69 & 8.65 \\
\hline
\end{tabular}




\begin{tabular}{|c|c|c|c|c|c|c|c|c|}
\hline \multicolumn{9}{|c|}{ Lower Subalpine zone } \\
\hline 1 & Tsuga dumosa & 175 & 23.49 & 94.23 & 52.71 & 0.8 & 21.05 & 97.25 \\
\hline 2 & $\begin{array}{l}\text { Rhododendron } \\
\text { anthopogon }\end{array}$ & 305 & 40.94 & 43.73 & 24.46 & 0.8 & 21.05 & 86.45 \\
\hline 3 & Rhododendron arboreum & 135 & 18.12 & 15.47 & 8.65 & 0.8 & 21.05 & 47.83 \\
\hline 4 & Quercus semecarpifolia & 105 & 14.09 & 24.38 & 13.64 & 0.4 & 10.53 & 38.26 \\
\hline 5 & Acer species & 5 & 0.67 & 0.29 & 0.16 & 0.4 & 10.53 & 11.36 \\
\hline 6 & Betula utilis & 10 & 1.34 & 0.26 & 0.14 & 0.2 & 5.26 & 6.75 \\
\hline 7 & Pyrus species & 5 & 0.67 & 0.40 & 0.23 & 0.2 & 5.26 & 6.16 \\
\hline 8 & Viburnum species & 5 & 0.67 & 0.01 & 0.01 & 0.2 & 5.26 & 5.94 \\
\hline \multicolumn{9}{|c|}{ Upper Temperate zone } \\
\hline $\mathbf{1}$ & Quercus semecarpifolia & 305 & 35.26 & 15.97 & 13.99 & 0.8 & 17.39 & 66.64 \\
\hline 2 & Tsuga dumosa & 120 & 13.87 & 31.62 & 27.71 & 0.6 & 13.04 & 54.63 \\
\hline 3 & Rhododendron arboreum & 155 & 17.92 & 8.54 & 7.48 & 0.6 & 13.04 & 38.45 \\
\hline 4 & Lyonia ovalifolia & 95 & 10.98 & 15.74 & 13.79 & 0.6 & 13.04 & 37.82 \\
\hline 5 & Lithocarpus elegans & 70 & 8.09 & 18.71 & 16.39 & 0.2 & 4.35 & 28.83 \\
\hline 6 & Pinus wallichiana & 25 & 2.98 & 9.80 & 8.58 & 0.6 & 13.04 & 24.52 \\
\hline 7 & Lindera pulcherima & 60 & 6.94 & 3.39 & 2.97 & 0.4 & 8.70 & 18.60 \\
\hline 8 & $\begin{array}{l}\text { Rhododendron } \\
\text { anthopogon }\end{array}$ & 10 & 1.16 & 8.84 & 7.75 & 0.2 & 4.35 & 13.25 \\
\hline 9 & Quercus lantana & 10 & 1.16 & 0.93 & 0.82 & 0.2 & 4.35 & 6.32 \\
\hline $\mathbf{1 0}$ & Betula species & 10 & 1.16 & 0.49 & 0.43 & 0.2 & 4.35 & 5.94 \\
\hline 11 & Symploccus species & 5 & 0.58 & 0.09 & 0.08 & 0.2 & 4.35 & 5 \\
\hline \multicolumn{9}{|c|}{ Lower Temperate zone } \\
\hline 1 & Lithocarpus elegans & 60 & 13.04 & 17.10 & 24.65 & 0.4 & 8.70 & 46.39 \\
\hline 2 & Pinus wallichiana & 60 & 13.04 & 10.55 & 15.22 & 0.4 & 8.70 & 36.95 \\
\hline 3 & Lyonia ovalifolia & 70 & 15.22 & 4.75 & 6.85 & 0.6 & 13.04 & 35.11 \\
\hline 4 & Alnus nepalensis & 30 & 6.52 & 15.70 & 22.63 & 0.2 & 4.35 & 33.50 \\
\hline 5 & Rhododendron arboreum & 95 & 20.65 & 1.65 & 2.38 & 0.4 & 8.70 & 31.72 \\
\hline 6 & Lindera pulcherima & 40 & 8.70 & 5.83 & 8.41 & 0.6 & 13.04 & 30.15 \\
\hline 7 & Berberis species & 10 & 2.17 & 1.10 & 1.58 & 0.4 & 8.70 & 12.45 \\
\hline 8 & Quercus lantana & 15 & 3.26 & 2.68 & 3.86 & 0.2 & 4.35 & 11.47 \\
\hline 9 & Galechop* & 25 & 5.43 & 0.62 & 0.89 & 0.2 & 4.35 & 10.67 \\
\hline 10 & Pyrus pashia & 15 & 3.26 & 1.92 & 2.76 & 0.2 & 4.35 & 10.37 \\
\hline 11 & Juglans regia & 5 & 1.09 & 3.25 & 4.69 & 0.2 & 4.35 & 10.12 \\
\hline 12 & Elaegnus species & 5 & 1.09 & 2.81 & 4.04 & 0.2 & 4.35 & 9.48 \\
\hline 13 & Lagerstroemia parvilora & 15 & 3.26 & 1.08 & 1.56 & 0.2 & 4.35 & 9.17 \\
\hline 14 & Rhus species & 10 & 2.17 & 0.23 & 0.34 & 0.2 & 4.35 & 6.86 \\
\hline 15 & Quercus glauca & 5 & 1.09 & 0.10 & 0.14 & 0.2 & 4.35 & 5.58 \\
\hline
\end{tabular}

Abbreviations are: RD relative density; BA Basal area; RBA Relative basal area; F frequency; RF Relative frequency; IVI importance value index. Galechop* (local name) broadleaf unidentified species. 
In the Upper Temperate zone (2500-3000 m asl), eleven species were recorded (Table 1). Here, Quercus semecarpifolia was the ecologically most important species for this zone with an IVI value of 66.64. The second was Tsuga dumosa with an IVI value of 54.63. Among the other nine associated tree species, Symploccus spp. was the least important species. In the Lower Temperate zone (2000-2500 m asl), altogether fifteen species were recorded (Table 1). Among them Lithocarpus elegans was the ecologically most important species for this zone with an IVI value of 46.39. Pinus wallichiana, Lyonia ovalifolia, Alnus nepalensis, Rhododendron arboreum and Lindera Pulcherima were also found to be ecologically important species in this zone. Quercus glauca was found to be the least important species.

The species composition of trees of each vegetation zone was analyzed. The recorded tree species and their corresponding vegetation zones, indicator value (IV) and $p$ value are shown in (Table 2). Out of 25 tree species, only four species showed a significant preference to a specific zone. Species Rhododendron campanulatum and Tsuga dumosa preferred the Upper Subalpine zone, similarly Rhododendron anthopogon and Quercus semecarpifolia preferred Lower Subalpine zone and Upper Temperate zone respectively (Table 2).

Table 2. Indicator species analysis of all recorded tree species in an elevation gradient of each vegetation zone

\begin{tabular}{|c|c|c|c|c|c|}
\hline Species & $\begin{array}{l}\text { Vegetation } \\
\text { zones }\end{array}$ & $\begin{array}{c}\text { Observed } \\
\text { indicator } \\
\text { value (IV) }\end{array}$ & $\begin{array}{c}\text { Randomized } \\
\text { groups } \\
\text { mean }\end{array}$ & S. Dev & $\begin{array}{c}P \\
\text { value }\end{array}$ \\
\hline Rhododendron arboreum & LSA & 28.1 & 28.4 & 10.19 & - \\
\hline Lindera pulcherima & $\mathrm{LT}$ & 24 & 25.1 & 12.61 & - \\
\hline Pinus wallichiana & LT & 28.2 & 24.3 & 11.95 & - \\
\hline Lyonia ovalifolia & UT & 34.5 & 26.1 & 11.79 & - \\
\hline Quercus lanata & $\mathrm{LT}$ & 12 & 17.6 & 11.24 & - \\
\hline Lithocarpus elegans & $\mathrm{LT}$ & 18.5 & 20.6 & 11.81 & - \\
\hline Pyrus pashia & $\mathrm{LT}$ & 20 & 20 & 0.28 & - \\
\hline Juglans regia & LT & 20 & 20 & 0.28 & - \\
\hline Berberis species & LT & 20 & 20.3 & 0.28 & - \\
\hline Elaegnus species & $\mathrm{LT}$ & 20 & 20 & 0.28 & - \\
\hline Galechop* & $\mathrm{LT}$ & 20 & 20 & 0.28 & - \\
\hline Lagerstroemia parvilora & LT & 20 & 20 & 0.28 & - \\
\hline Alnus nepalensis & LT & 20 & 20 & 0.28 & - \\
\hline Rhus species & LT & 20 & 20 & 0.28 & - \\
\hline Quercus glauca & LT & 20 & 20 & 0.28 & - \\
\hline Tsuga dumosa & USA & 50.8 & 31.7 & 9.48 & * \\
\hline Rhododendron anthopogon & LSA & 77.5 & 25.4 & 12.6 & $* *$ \\
\hline Quercus semecarpifolia & UT & 59.5 & 30.8 & 14.31 & $*$ \\
\hline Symploccus species & UT & 20 & 20 & 0.28 & - \\
\hline Acer species & LSA & 20 & 20 & 0.28 & - \\
\hline
\end{tabular}




\begin{tabular}{|l|r|r|r|r|r|}
\hline Viburnum species & LSA & 20 & 20 & 0.28 & - \\
\hline Betula utilis & LSA & 13.3 & 19.3 & 11.11 & - \\
\hline Pyrus species & LSA & 20 & 20 & 0.28 & - \\
\hline Rhododendron campanulatum & USA & $\mathbf{1 0 0}$ & $\mathbf{2 3 . 6}$ & $\mathbf{1 0 . 8 3}$ & *** \\
\hline Juniperus recurva & USA & 40 & 17.1 & 11.75 & - \\
\hline Averages & - & 29.86 & 22.01 & 6.18 & - \\
\hline
\end{tabular}

* Monte Carlo test of significance of observed maximum indicator value for variable 4999 permutations, random number seed: 1146 . Proportion of randomized trials with indicator value equal to or exceeding the observed indicator value. $\mathrm{p}=(1+$ number of runs $>=$ observed $) /(1+$ number of randomized runs $)$. Vegetation zones = Group identifier for group with maximum observed IV. Bold Significant species. ""not significant, *Significant at $0.05<\mathrm{p}<0.01, * *$ Significant at $0.01<\mathrm{p}<0.001$, and $* * *$ Significant at $\mathrm{p}<0.001$. Abbreviation for zones; USA $=$ Upper Subalpine, LSA $=$ Lower Subalpine, UT $=$ Upper Temperate, and LT $=$ Lower Temperate.

\section{Forest structure}

The total number of stems, total basal area and average tree height in each elevation is presented in Fig.2. It shows the trend of stand features along the altitudinal gradient. Within the sampling plots, total number of stems $(\geq 5 \mathrm{~cm} \mathrm{dbh})$ inventoried per plot fluctuated from 275 per hectare at $2100 \mathrm{~m}$ asl to 1700 trees per hectare at $2800 \mathrm{~m}$ asl. The number of stems was highly fluctuating among the plots along elevation, beyond $3700 \mathrm{~m}$ asl, it is decreasing. The total basal area on the plots varied from $10.43 \mathrm{~m}^{2} \mathrm{ha}^{-1}$ at $3900 \mathrm{~m}$ asl to $248.41 \mathrm{~m}^{2} \mathrm{ha}^{-1}$ at $3200 \mathrm{~m}$ asl. It was found to be increasing to an elevation about $3200 \mathrm{~m}$ asl and getting lower in higher elevation. The average tree height was maximum at $2100 \mathrm{~m}$ asl $(30.03 \mathrm{~m})$ and minimum in the highest plot at $3900 \mathrm{~m}$ asl $(2.44 \mathrm{~m})$. The average height of tree stands in each plot was found to be slightly decreased with increasing altitude. However, the high value in the plots situated at $2900 \mathrm{~m}$ asl and $3400 \mathrm{~m}$ asl was because of high number of Tsuga dumosa (13 out of 19 individuals) and (17 out of 24 individuals) respectively (Appendix Table Al).

The forest structure parameters were measured per vegetation zones. Stem density was found to be maximum in Upper Temperate zone ( 865 trees $^{\mathrm{ha}^{-1}}$ ) and minimum in Lower Temperate zone (460 trees $\mathrm{ha}^{-1}$ ) (Table 3). The analysis of size class distribution of tree stems inventoried in the entire sampling plots showed that the Upper Subalpine zone, Upper Temperate zone and Lower Temperate zone had maximum percentages of trees in the $10-29.9 \mathrm{~cm}$ DBH range. In contrast to this, the maximum percentages $(55.1 \%)$ of trees were recorded in $\geq 30 \mathrm{~cm}$ dbh range in the Lower Subalpine zone. The average tree height $(>5 \mathrm{~cm}$ dbh) by vegetation zones is shown in Table3. The highest average tree height was found in the Lower Subalpine Zone $(20.04 \mathrm{~m})$ and the lowest in the Upper Temperate zone $(13.81 \mathrm{~m})$. The more dispersed values were observed for Upper Subalpine and Lower Temperate zone as indicated by their elevated standard deviation (SD). The average basal area of tree species was found to be maximum in the Lower Subalpine zone $\left(22.43 \mathrm{~m}^{2} \mathrm{ha}^{-1}\right)$ and minimum in Lower Temperate zone $\left(4.56 \mathrm{~m}^{2} \mathrm{ha}^{-1}\right)$. The vegetation zone with higher basal area (Lower Subalpine zone) showed high variability which is also denoted by the elevated standard deviation encountered compared to other zones (Table 3). 
Table 3. Number of trees per hector (\%) by diameter size and average tree height by vegetation zones

\begin{tabular}{|c|c|c|c|c|c|c|c|c|}
\hline \multirow[t]{2}{*}{ Vegetation zones } & \multicolumn{3}{|c|}{$\begin{array}{l}\text { \% of Stems/ha by } \\
\text { diameter classes }\end{array}$} & \multirow{2}{*}{$\begin{array}{l}\text { Total } \\
\text { stems } \\
\text { (no/ha) }\end{array}$} & \multicolumn{2}{|c|}{$\begin{array}{l}\text { Average tree } \\
\text { height }\end{array}$} & \multicolumn{2}{|c|}{$\begin{array}{l}\text { Average basa } \\
\text { area }\end{array}$} \\
\hline & $\begin{array}{l}<10 \\
\mathrm{~cm}\end{array}$ & $\begin{array}{c}10-29.9 \\
\mathrm{~cm}\end{array}$ & $\begin{array}{l}\geq 30 \\
\mathrm{~cm}\end{array}$ & & $\mathrm{~m}$ & $\pm \mathrm{SD}$ & $\mathrm{m}^{2} / \mathrm{ha}$ & $\pm \mathrm{SD}$ \\
\hline Upper Subalpine & 12.5 & 51.1 & 36.3 & 840 & 14.06 & 9.42 & 18.49 & 18.69 \\
\hline Lower Subalpine & 8.7 & 36.2 & 55.1 & 745 & 20.04 & 7.82 & 22.43 & 33.01 \\
\hline $\begin{array}{l}\text { Upper } \\
\text { Temperate }\end{array}$ & 6.9 & 53.8 & 39.3 & 865 & 13.81 & 5.88 & 10.37 & 9.63 \\
\hline $\begin{array}{l}\text { Lower } \\
\text { Temperate }\end{array}$ & 6.5 & 48.9 & 44.6 & 460 & 14.06 & 9.14 & 4.56 & 5.48 \\
\hline
\end{tabular}
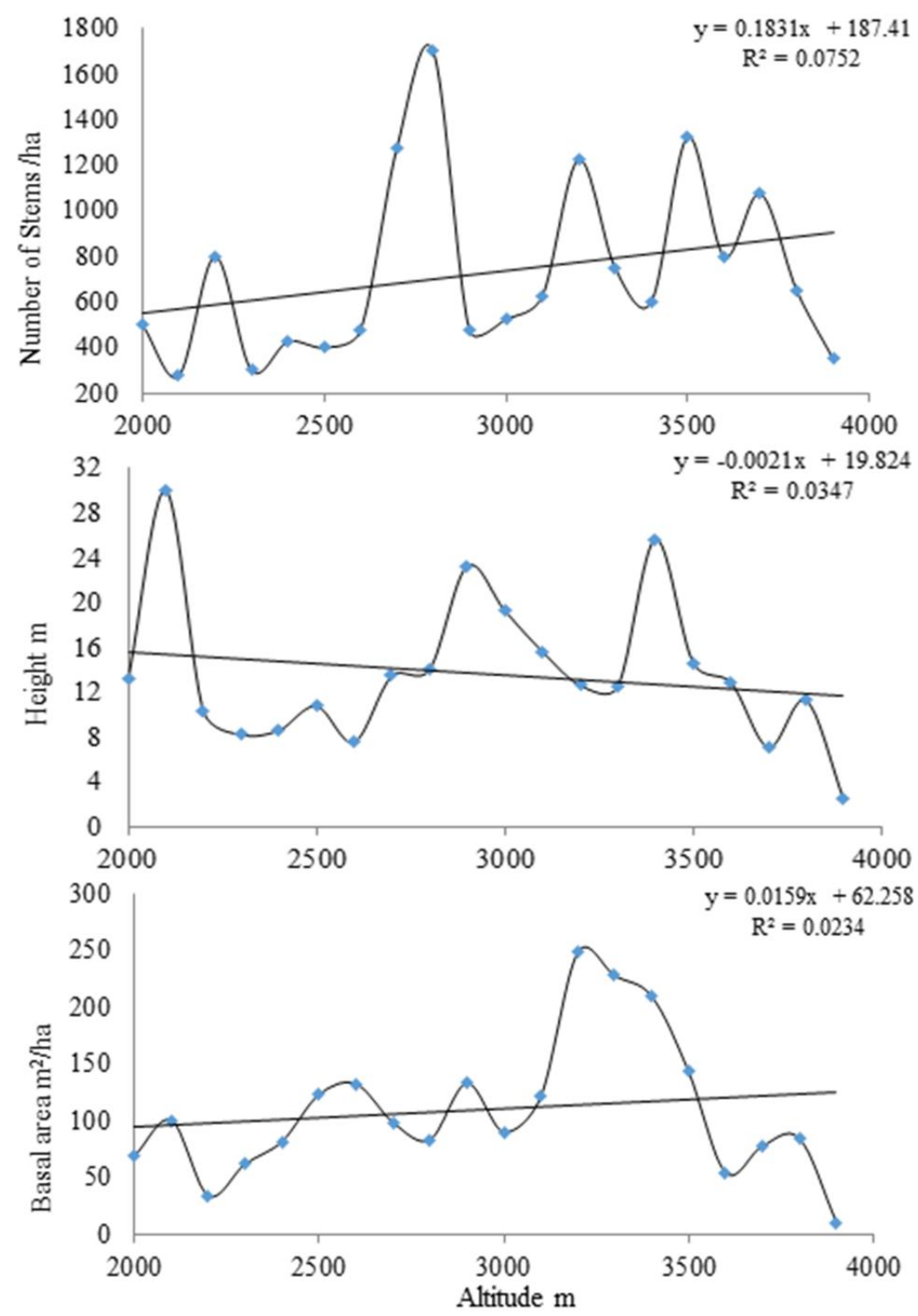

Figure 2. The tendency of no. of stems, height and basal area ha ${ }^{-1}$ in each 20 plots along the elevation gradient $(2000 \mathrm{~m}-3900 \mathrm{~m}$ asl). Figure shows the trend of stand features (total no. of stems, total basal area and average tree height along the altitude. 


\section{Species diversity}

Tree species diversity was calculated for the four vegetation zones separately (Fig. 3). The values of Shannon index, Simpson index and Evenness index showed variations among the vegetation zones. The Shannon index which measures diversity in categorical data ranged from 1.10 to 2.34 . The peak value along the elevation zone centered around 2500-3000 $\mathrm{m}$ asl in the Lower Temperate zone while it was found to be least in the Upper Subalpine zone. The values of this index were found to be gradually increasing with decreasing altitude.

The Simpson index which measures the probability that two randomly selected individuals from a sample will belong to the same species, ranged from 0.65 to 0.89 The Lower Temperate zone exhibited the maximum value while the Upper Subalpine zone constituted the least value.

There was no distinct trend for this index with increasing altitude. The evenness index which measures the degree of equal distribution of individuals within the whole species pool ranged from to 0.69 to 0.86 . The Lower Temperate zone exhibited the maximum value while the Lower Subalpine zone constituted the least value.

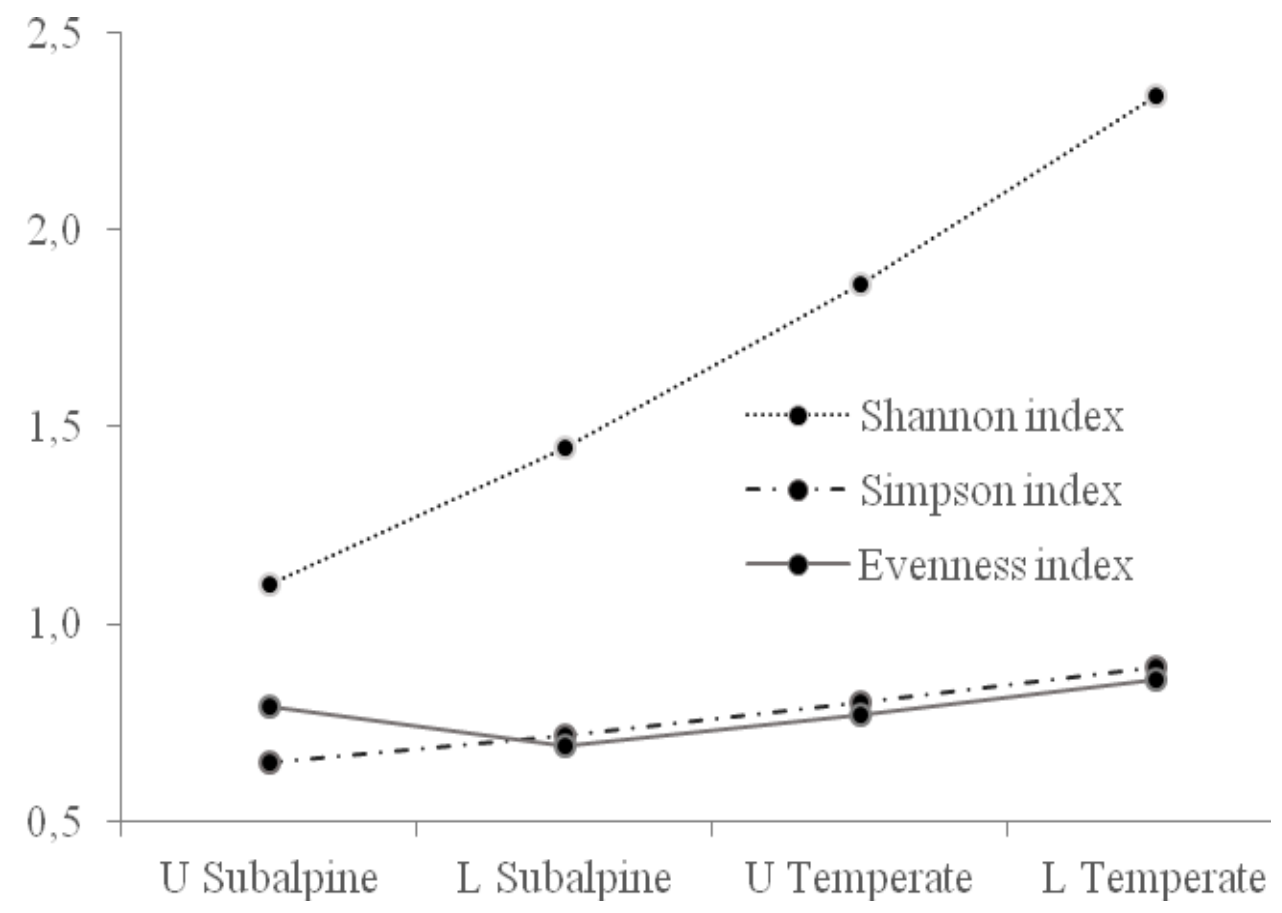

Figure 3. Tree diversity along the altitudinal gradient ( $U=$ Upper; $L=$ Lower)

\section{Discussion}

This study attempted to assess the structure, composition and diversity of natural forest stands in forests in the LNP of Nepal in Central Himalaya. The results derived from this study provide baseline information regarding potential of the protected area to secure conservation of species along an altitudinal gradient. The results are further discussed in the following sections. 


\section{Forest composition}

Altitude is one of the most important determinants of tree distribution due to its direct impact on the microclimate of the habitat (Adhikari et al., 2012a). In the present study importance values of species differed along the altitude. This reflects the relative importance of each species in a spectrum of climax communities established in the park (Pandey, 2015). The variability of the distribution of plant species in the sampling plots at each vegetation zones could be attributed to the effect of co-factors like topography, aspect and exposure within the same altitudinal range. Climatic variations influenced by the complex topography in a predominantly monsoonal area most often determine the dominant type of vegetation in the park. The vegetation zones are partly obscured by factors of aspect, drainage, soil and human impact (Neilson et al., 2006).

The floristic composition of tree species differs at different altitudinal zones based on indicator value. Rhododendron campanulatum is highly significant $(p<0.001)$ and Tsuga dumosa is significant $(0.05<p<0.01)$ in the Upper Subalpine zone respectively. Rhododendron anthopogon indicates the Lower Subalpine zone with significant value $(0.01<p<0.001)$. Similarly, the Quercus semecarpifolia prefers the altitudinal range of the Upper Temperate zone. However, other species show their appearance in their respective zones but without significant preference.

\section{Forest structure}

Structural characteristics such as stem densities, basal area, dbh and height of tree are a function of the forest type, edaphic conditions, and the age and degree of disturbance of each stand. Here, the results derived from this study are compared and contrasted with the results found in similar kind of forests outside LNP. The vegetation zones in LNP showed average tree density ( $\geq 5 \mathrm{~cm}$ dbh) values from 460 to 865 per hectare which is consistent with the density values of 295 and 850 tree ha $^{-1}$ $(\geq 10 \mathrm{~cm} \mathrm{dbh}$ ) for major types of protected forests in Indian forests reported by Sharma et al. (2010). Tree density of our study is comparatively higher than the values in the Moist Temperate Conifers zone $\left(90 \mathrm{ha}^{-1}\right)$ and in Central Himalayan Moist Temperate Forest (170-283 ha ${ }^{-1}$ ) (Chaturvedi and Singh, 1986; Shaheen et al., 2012). The range of stem density values observed in other studies ranged between 420-1300 trees ha ${ }^{-1}$ in Kumaun Himalaya (Saxena and Singh, 1982), and 990-1470 trees ha ${ }^{-1}$ in western Himalaya (Gairola et al., 2011) in 1200 to $2500 \mathrm{~m}$ asl range. In this study, the average height of tree species recorded was maximum in the Lower Subalpine zone (3000$3500 \mathrm{~m}$ asl). In contrast to this, some of the tallest and largest trees in the Himalaya were reported between 2500 and $3000 \mathrm{~m}$ by Singh and Singh (1987). They had also revealed that with further rise in elevation, in response to a sudden decline in the rainfall, and in severely cold and windy conditions, tree height of Himalayan forests were found to be reduced drastically. In this study, canopy height was also found to be slightly decreased with the elevation in LNP. In our study, the total basal area for sampling plots in LNP ranged from 10.43 to $248.41 \mathrm{~m}^{2}$ ha $^{-1}$ which is higher than the findings from other studies in Himalayan region such as 78-92 $\mathrm{m}^{2} \mathrm{ha}^{-1}$ in lesser Himalayan Moist Temperate forests (Ahemed et al., 2006); 90- $152 \mathrm{~m}^{2} \mathrm{ha}^{-1}$ in trans Himalayan forests of Nepal (Kunwar and Sharma, 2004); 86-129 $\mathrm{m}^{2} \mathrm{ha}^{-1}$ in Garwal Himalayas (Pandey, 2001). 


\section{Tree diversity}

In Nepalese Himalaya, the number of species in $100 \mathrm{~m}$ altitudinal bands increases steeply with altitude until $1,500 \mathrm{~m}$ above sea level. Between 1,500 and $2500 \mathrm{~m}$, little change in the number of species has been observed, but above this altitude, a decrease in species richness is evident (Vetaas and Grytnes, 2002). The results of this study also reflect this general trend found in plant diversity of mountain forests in Himalaya. Oommen and Shanker (2005) provided evidence for different mechanisms along spatial scales and explained a mechanism based on the investigations on woody plant diversity in the Indian Western Himalaya. They revealed that the species with high tolerance to climatic variability had followed mid-domain model predictions, and showed a nonlinear relationship with temperature, whereas tropical species richness tracked temperature and area. The Shannon diversity values recorded (1.10 to 2.34 ) in our study lies close to the reported range of 1.16 to 3.40 for the Himalayan range (Pandey, 2001, Kunwar and Sharma, 2004). Maximum value of evenness in Lower temperate zone represented homogeneous communities having similar species distribution. Low evenness values of forest communities in Lower Subalpine zone and Upper Temperate zone can possibly be due to suppression and out-shading of associated species by the dominant conifers obtaining maximum amount of light and water. A similar result was found in Colombian fragmented forest by Murcia (1995).

\section{Limitation of the study}

This study has attempted to explore the structure, composition, and floristic diversity of forest vegetation of the Langtang National Park along the altitudinal gradient. However, it has some limitation as follows: this study is limited to i) sample replications, ii) important site characteristics such as: slope, edaphic factors, iii) elevation limited (2000-3900). Finally, we will consider these short comes of the research and formulate some hypotheses and test on an experimental fieldwork in the future.

\section{Outlook}

The understanding of forest structure, composition and diversity in natural forests is the basis for sustainable management of any forest ecosystem. Suwal et al. (2014) have reported that people overused the forest products (timber and non-timber) from LNP despite its legal protection. This combined with potential negative implications of future climate change on ecosystem function in the Himalayan forests, highlights the urgent need for conservation attention. The knowledge derived from this study can be useful to identify priorities for management and biodiversity conservation in such forests in the future. With the increasing focus on ecosystem services, protected areas are now also seen as a crucial component of global climate change mitigation efforts (Soares-Filho et al., 2010; Watson et al., 2014). The vegetation zones with distinct forest structure, composition and diversity in LNP may facilitate gains for both adaptation of climate and key of forest conservation in the future. The information and monitoring of ecological indicator species in particular zones of the study area can provide hints about adaptability of species in typical forest ecosystem, which will play important role in forest management strategies especially post-earthquake situation. 
Acknowledgements. We thank to the Department of National Park and Wildlife Conservation (DNPWC), Nepal for providing research permission in Langtang National Park. We are indebted to Dr. K. Bista for significant comments on the first draft of manuscripts. We also thank to anonymous reviewers for critical reading and valuable comments on the manuscript.

\section{REFERENCES}

[1] Adhikari, Y.P., Fischer, A. (2011): Distribution pattern of the epiphytic orchid Rhynchostylis retusa under strong human influence in Kathmandu valley, Nepal. Botanica Orientalis - Journal of Plant Science 8: 90-99, DOI: http://dx.doi.org/10.3126/botor.v8i0.5956.

[2] Adhikari, Y.P., Fischer, H.S., Fischer, A. (2012a): Micro-site conditions of epiphytic orchids in a human impact gradient in Kathmandu valley, Nepal. - Journal of Mountain Science 29: 331-342, DOI: 10.1007/s11629-009-2262-1.

[3] Adhikari, Y.P., Fischer, H.S., Fischer, A. (2012b): Host tree utilization by epiphytic orchids in different land-use intensities in Kathmandu valley, Nepal. - Plant Ecology 213: 1393-1412, DOI: 10.1007/s11258-012-0099-0.

[4] Adhikari, Y.P., Fischer, A., Pauleit, S. (2015): Sustainable conservation perspectives for epiphytic orchids in the central Himalayas, Nepal. - Applied Ecology and Environmental Research 13: 753-767, DOI:10.15666/aeer/1303_753767.

[5] Adhikari, Y.P., Fischer, H.S., Fischer, A. (2016): Epiphytic orchids and their ecological niche under anthropogenic influence in central Himalayas, Nepal. - Journal of Mountain Science (in Press). DOI : 10.1007/s11629-015-3751-z.

[6] Ahmed, M., Husain T., Heikh, A.H.S., Hussain S.S., Siddiqui, M. (2006): Phytosociology and structure of Himalayan forests from different climatic zones of Pakistan. - Pakistan Journal of Botany 38: 361-383.

[7] Barthlott, W., Lauer, W., Placke, A. (1996): Global distribution of species diversity in vascular plants: towards a world map of phytodiversity. - Erdkunde 50: 317 -327

[8] Bhuju, U.R., Shakya, P.R., Basnet, T.B. Shrestha, S. (2007): Nepal Biodiversity Resource Book- Protected Areas, Ramsar Sites and World Heri-tage Sites. 1st ed. ICIMOD, Kathmandu.

[9] Campbell, A., Miles. L., Lysenko, I., Hughes, A., Gibbs, H. (2008): Carbon storage in protected areas: Technical report. - UNEP World Conservation Monitoring Centre.

[10] Canadell, J.G., Le Quere, C., Raupach, M.R., Field, C.B., Buitenhuis, E.T., Ciais, P., Conway, T.J., Gillett, N.P., Houghton, R.A., Marland, G. (2007): Contributions to accelerating atmospheric $\mathrm{CO}_{2}$ growth from economic activity, carbon intensity, and efficiency of natural sinks. - Proceedings of the National Academy of Sciences, USA 104: 18866-18870.

[11] Chaturvedi, O.P., Singh, J.S. (1986): The structure and function of pine forest in central Himalayan I: Dry matter dynamics. - Annals of Botany 60:237-252.

[12] Chytry, M., Otypkova, Z. (2003): Plot sizes used for phytosociological sampling of European vegetation. - Journal of Vegetation Science 14: 563-570.

[13] Curtis, J. T., McIntosh, R.P. (1951): An upland forest continuum in the prairie-forest border region of Wisconsin. - Ecology 32: 476-496.

[14] Denman, K.L., Brasseur,G.A., Ciais, C.P., Cox, P.M., Dickinson, R.E., Hauglustaine, D.C., Holland, H.E., Jacob, D., Lohmann, U., Ramachandran, S., da Silva Dias, P.L., Wofsy, S.C., Zhang, X. (2007): Couplings Between Changes in the Climate System and Biogeochemistry. - In: S. Solomon, D. Qin, M. Manning, Z. Chen, M. Marquis, K.B. Averyt, M. Tignor, H.L. Miller (eds.) Climate Change 2007: The Physical Science Basis. Contribution of Working Group I to the Fourth Assessment Report of the 
Intergovernmental Panel on Climate Change. Cambridge University Press, Cambridge, United Kingdom and New York, NY, USA.

[15] DFRS (1999): Forest Resources of Nepal (1987-1998). Department of Forest Research and Survey, Ministry of Forest and Soil Conservation, Kathmandu, Nepal.

[16] Dobremez, J.F. (1976): Le Népal. Ecologie et Biogeography, CNRS Paris. Pp131-257.

[17] Dudley, N. (2009): Use of protected areas as tools to apply REDD carbon offset schemes. - Policy Matters 16: 99-108.

[18] Dufrêne, M., Legendre, P. (1997): Species assemblages and indicator species: the need for a flexible asymmetrical approach. - Ecological Monographs 67: 345-366.

[19] Fischer, A. (2011): Altitudinal gradients in biodiversity research: the state of the art and future perspectives under climate change aspects. - Waldökologie, Landschaftsforschung und Naturschutz 11: 35-47.

[20] Gairola, S., Sharma, C.M., Suyal, S., Ghildiyal, S.K. (2011): Species composition and Diversity in Mid-altitudinal Moist Temperate Forests of the Western Himalaya. - Journal of Forest Science 27: 1-15.

[21] Gutierrez, A.G., Huth, A. (2012): Successional stages of primary temperate rain forests of Chiloe Island, Chile. Perspect. - Plant Ecology and Evolution Systematics 14: 243-256.

[22] IPCC (2007): Climate change 2007: The physical science basis. -In: Solomon S., D. Qin, M. Manning, Z. Chen, M. Marquis, K.B. Averyt et al. editors. Contribution of working group I to the fourth assessment report of the intergovernmental panel on climate change. Cambridge and New York: Cambridge University Press. Pp996.

[23] IPCC (2013): Climate Change 2013: The Physical Science Basis. Contribution of Working Group I to the Fifth Assessment Report of the Intergovernmental Panel on Climate Change [Stocker, T.F., D. Qin, G.K. Plattner, M. Tignor, S.K. Allen, J. Boschung, A. Nauels, Y. Xia, V. Bex and P.M. Midgley (eds.)]. Cambridge University Press, Cambridge, United Kingdom and New York, NY, USA. Pp1535.

[24] Körner, C. (2007): The use of 'altitude' in ecological research. - Trends in Ecology and Evolution 22: 569-574.

[25] Kunwar, R.M., Sharma, S.P. (2004): Quantitative analysis of tree species in two community forests of Dolpa district, mid-west Nepal. - Himalaya Journal of Science 2: 23-28.

[26] LNP (1977): Langtang National Park management plan (1977-1982). Department of National Parks and Wildlife Conservation, Kathmandu, Nepal.

[27] McCune, B., Mefford, M.J. (2011): PC-ORD. Multivariate Analysis of Ecological Data. Version 6. MjM Software, Gleneden Beach, Oregon, U.S.A.

[28] Müller-Dombois, D., Ellenberg, H. (1974): Aims and Methods of Vegetation Ecology. Wilez and Sons. J., New York, London, Sydney, Toronto. Pp 547.

[29] Murcia, C. (1995): Edge effects in fragmented forest: Implications for conservation. Trends in ecological and evolution 10: 58-62.

[30] Neilson, E.T., MacLean, D.A., Arp, P.A., Meng, F-R., Bourque, C.P-A., Bhatti, J. S. (2006): Modeling carbon sequestration with CO2 Fix and a timber supply model for use in forest management planning. - Canadian Journal of Soil Science 86: 219-233.

[31] Oshawa, M. (1977): Altitudinal zonation of vegetation in eastern Nepal Himalaya. Pedologist 21: 76-94.

[32] Oshawa, M. (1984): Differentiation of vegetation zones and species strategies in the Subalpine region Mt. Fuji. - Vegetatio 57: 15-52. DOI: 10.1007/BF0003192.

[33] Oommen, M.A. Shanker, K. (2005): Elevational species richness patterns emerge from multiple local mechanisms in Himalayan woody plants. - Ecology 86: 3039-3047.

[34] Pandey, K.P. (2015): Assessment of structure, composition and carbon stocks of forests along the elevational gradient in the Langtang National Park, Nepal. M. Sc. (Sustainable Resource Management) Thesis Technische Universität München. 
[35] Pandey, P.K. (2001): Quantitative vegetation analysis as per aspect and altitude, and regeneration behaviour of tree species in Garhwal Himalayan forest. - Annual Forestry 9: 39-52.

[36] Pielou, E. C. (1969): An Introduction to Mathematical Ecology. - Wiley, New York. Pp286.

[37] Polunin O., Stainton A. (2000): Flowers of the Himalaya. - Oxford University Press, New Delhi. Pp580.

[38] Pretzsch, H. (2009): Forest Dynamics, Growth and Yield. Springer, Berlin- Heidelberg.

[39] Richards, K.R., Stokes, C. (2004): A Review of Forest Carbon Sequestration Cost Studies: A Dozen Years of Research. - Climatic Change 63: 1-48.

[40] Saxena, A.K., Singh, J.S. (1982): A phytosociological analysis of woody species in forest communities of a part of Kumaun Himalaya. - Vegetatio 50: 3-22.

[41] Scharlemann, J.P.W., Kapos, V., Campbell, A., Lysenko, K., Burgess, N.D., Hansen, M.C., Gibbs, H.K., Dickson, B., Miles, L. (2010): Securing tropical forest carbon: The contribution of protected areas to REDD. - Oryx 44: 352-357.

[42] Schweinfurt, U. (1957): Die horizontalae und vertikale Verbreitung der vegetation im Himalaya. Bonn. Geogr. Abh., H 20. Bonn. Pp1-373.

[43] Shaheen H., Ullah, Z., Khan, S.M., Harper, D.M. (2012): Species composition and community structure of western Himalayan moist Temperate forests in Kashmir. - Forest Ecology and Management 178: 138-145.

[44] Sharma, C.M., Baduni, N.P., Gairola, S., Ghidiyal, S.K., Suyal, S. (2010): Tree diversity and carbon stocks of some major forest types of Garhwal Himalaya, India. - Forest Ecology and Management 260: 2170-2179.

[45] Shrestha, T. B. (2001): Forest diversity of Nepal's protected areas in the mountains. The Himalayan Review 32: 25-28.

[46] Simpson, E.H. (1949): Measurement of diversity. - Nature 163: 688.

[47] Singh, J.S. Singh, S.P. (1987): Forest Vegetation of the Himalayas. - Botanical Review 53: 81-181.

[48] Soares-Filho, B., Moutinho, P., Nepstad, D., Anderson, A., Rodrigues, H., Garcia, R., Dietzsch, L., Merry, F., Bowman, M., Hissa, L., Silvestrini, R., Maretti, C. (2010): Role of Brazilian Amazon protected areas in climate change mitigation. - Proccedings National Academy of Science USA 107: 10821-10826.

[49] Stainton, J.D.A. (1972): Forests of Nepal. - John Murray, London.

[50] Suwal, A.L., Bhuju, D.R., Maren, I.E. (2014): Assessment of Forest Carbon Stocks in the Himalayas: Does Legal Protection Matter? - Small-scale Forestry Pp14. DOI: 10.1007/s11842-014-9276-4.

[51] UNFCCC (2007): .Report of the conference of the parties on its thirteenth session, held in Bali from 3 to 15 December 2007. Decision /FCCC/CP/2007/6/Add.1, Decision 2/CP.13.

[52] Vetaas, O.R., Grytnes, J. (2002): Distribution of vascular plant species richness and endemic richness along the Himalayan elevation gradient in Nepal. - Global Ecology and Biogeography 11: 291-301.

[53] Watson, J.E.M., Dudley, N., Segan, D.B., Marc-Hockings, M. (2014): The performance and potential of protected areas. - Nature 515: 67-73.

[54] WCSP (2015): World Checklist of Selected Plant Families. Facilitated by the Royal Botanic Gardens, Kew. Published on the Internet; http://apps.kew.org/wcsp/ Retrieved (2015-05-09).

[55] Weber, M. (2001): Kohlenstoffspeicherung in Lenga- (Nothofagus pumilio) Primärwäldern Feuerlands und Auswirkungen ihrer Überführung in Wirtschaftswald auf den C-Haushalt. Habilitationsschrift. Verlag Dr. Norbert Kessel. 119 S. 


\section{APPENDIX}

Table A1. Number of individuals, average height and dbh of each species inventoried per plot (plot one is the highest elevation and plot 5 is the lowest elevation) in each vegetation zone

\begin{tabular}{|c|c|c|c|c|c|c|c|c|c|}
\hline \multirow{2}{*}{$\begin{array}{l}\text { Vegetation } \\
\text { zones }\end{array}$} & \multirow[t]{2}{*}{ Species } & \multicolumn{6}{|c|}{ Plots } & \multirow{2}{*}{$\begin{array}{r}\text { Height } \\
(\mathrm{m})\end{array}$} & \multirow{2}{*}{$\begin{array}{r}\mathrm{dbh} \\
(\mathrm{cm})\end{array}$} \\
\hline & & 1 & 2 & 3 & 4 & 5 & Total & & \\
\hline \multirow{4}{*}{$\begin{array}{l}\text { Upper } \\
\text { Subalpine zone } \\
(3500-3900)\end{array}$} & $\begin{array}{l}\text { Rhododendron } \\
\text { campanulatum }\end{array}$ & 13 & 3 & 7 & 8 & 8 & 39 & 4.40 & 14.32 \\
\hline & Tsuga dumosa & 1 & 22 & 6 & 24 & 8 & 61 & 13.87 & 34.99 \\
\hline & Betula utilis & 0 & 1 & 0 & 0 & 0 & 1 & 5 & 26 \\
\hline & Juniperus recurva & 0 & 0 & 30 & 0 & 37 & 67 & 11.92 & 27.66 \\
\hline \multicolumn{2}{|c|}{ Total no. of individuals in each plot } & 14 & 26 & 43 & 32 & 53 & 168 & & \\
\hline \multirow{8}{*}{$\begin{array}{l}\text { Lower } \\
\text { Subalpine zone } \\
(3000-3500)\end{array}$} & Tsuga dumosa & 17 & 6 & 4 & 8 & 0 & 35 & 30.69 & 74.89 \\
\hline & Acer species & 0 & 0 & 0 & 1 & 0 & $\mathbf{1}$ & 6 & 27 \\
\hline & Rhododendron anthopogon & 7 & 21 & 30 & 0 & 3 & 61 & 9.26 & 33.90 \\
\hline & Rhododendron arboreum & 0 & 2 & 13 & 10 & 2 & 27 & 9.17 & 29.67 \\
\hline & Viburnum species & 0 & 1 & 0 & 0 & 0 & $\mathbf{1}$ & 6.50 & 6 \\
\hline & Betula utilis & 0 & 0 & 2 & 0 & 0 & 2 & 11.50 & 18 \\
\hline & Quercus semecarpifolia & 0 & 0 & 0 & 6 & 15 & 21 & 22.77 & 45.57 \\
\hline & Pyrus species & 0 & 0 & 0 & 0 & 1 & 1 & 7 & 32 \\
\hline \multicolumn{2}{|c|}{ Total no. of individuals in each plot } & 24 & 30 & 49 & 25 & 21 & 149 & & \\
\hline \multirow{11}{*}{$\begin{array}{l}\text { Upper } \\
\text { Temperate zone } \\
(2500-3000)\end{array}$} & Tsuga dumosa & 13 & 1 & 10 & 0 & 0 & 24 & 28.11 & 51.54 \\
\hline & Rhododendron anthopogon & 2 & 0 & 0 & 0 & 0 & 2 & 3.75 & 11.50 \\
\hline & Rhododendron arboreum & 0 & 11 & 12 & 8 & 0 & 31 & 7.39 & 30.61 \\
\hline & Quercus semecarpifolia & 2 & 53 & 5 & 1 & 0 & 61 & 15.40 & 21.31 \\
\hline & Lindera pulcherima & 2 & 0 & 10 & 0 & 0 & 12 & 8.86 & 24.17 \\
\hline & Betula species & 0 & 2 & 0 & 0 & 0 & 2 & 17 & 25 \\
\hline & Pinus wallichiana & 0 & 1 & 0 & 3 & 1 & 5 & 19.76 & 53 \\
\hline & Lyonia ovalifolia & 0 & 0 & 13 & 5 & 1 & 19 & 8.44 & 34.84 \\
\hline & Symplocus species & 0 & 0 & 1 & 0 & 0 & 1 & 9 & 15 \\
\hline & Quercus lanata & 0 & 0 & 0 & 2 & 0 & 2 & 6 & 32.5 \\
\hline & Lithocarpus elegans & 0 & 0 & 0 & 0 & 14 & 14 & 9.04 & 49.82 \\
\hline \multicolumn{2}{|c|}{ Total no. of individuals in each plot } & 19 & 68 & 51 & 19 & 16 & 173 & & \\
\hline \multirow{15}{*}{$\begin{array}{l}\text { Lower } \\
\text { Temperate zone } \\
(2000-2500)\end{array}$} & Rhododendron arboreum & 0 & 0 & 18 & 0 & 1 & 19 & 6.18 & 14.05 \\
\hline & Lindera pulcherima & 2 & 0 & 0 & 4 & 2 & 8 & 15.41 & 38.69 \\
\hline & Pinus wallichiana & 0 & 0 & 5 & 0 & 7 & 12 & 24.74 & 42.96 \\
\hline & Lyonia ovalifolia & 0 & 0 & 6 & 1 & 7 & 14 & 7.26 & 24.21 \\
\hline & Quercus lanata & 0 & 0 & 3 & 0 & 0 & 3 & 19.33 & 41.33 \\
\hline & Lithocarpus elegans & 4 & 8 & 0 & 0 & 0 & 12 & 8.26 & 50.42 \\
\hline & Pyrus pashia & 3 & 0 & 0 & 0 & 0 & 3 & 9 & 38.17 \\
\hline & Juglans regia & 1 & 0 & 0 & 0 & 0 & 1 & 31.80 & 91 \\
\hline & Berberis species & 1 & 1 & 0 & 0 & 0 & 2 & 5 & 36.75 \\
\hline & Elaegnus species & 1 & 0 & 0 & 0 & 0 & 1 & 9 & 84.50 \\
\hline & Galechop & 5 & 0 & 0 & 0 & 0 & 5 & 6.70 & 17.20 \\
\hline & Lagerstroemia parviflora & 0 & 3 & 0 & 0 & 0 & 3 & 7.33 & 30 \\
\hline & Alnus nepalensis & 0 & 0 & 0 & 6 & 0 & 6 & 36.50 & 79.67 \\
\hline & Rhus species & 0 & 0 & 0 & 0 & 2 & 2 & 6.25 & 17 \\
\hline & Quercus glaиса & 0 & 0 & 0 & 0 & 1 & 1 & 6.50 & 16 \\
\hline \multicolumn{2}{|c|}{ Total no. of individuals in each plot } & 17 & 12 & 32 & 11 & 20 & 92 & & \\
\hline
\end{tabular}

